\title{
To Study Surgical Management of Distal Femoral Fractures \& its Complication
}

\author{
Raman Shrivastava ${ }^{1}$, Namita Shrivastava ${ }^{2}$ \\ ${ }^{1}$ Assistant Professor, Division of Pediatric Orthopedics, Department of Pediatric Surgery, DKS PGI \& Research \\ Centre, Raipur. \\ ${ }^{2}$ Associate Professor, Department of Physiology, Pt. J. N. M. Medical College, Raipur.
}

Corresponding Author: Raman Shrivastava

\begin{abstract}
Background: Fractures of distal end of femur are complex injuries which are difficult to manage. These fractures often are unstable and comminuted. Despite advances in surgical techniques and improvement in implants, treatment of distal femoral fractures remains a challenge in many situations. This study was done to analyse the functional outcome and this management of distal femoral fractures with its complication.
\end{abstract}

Material \& Methods: This study has been done between August 2008 to March 2010 on patients coming to Orthopaedics Department at Jawaharlal Nehru Hospital and Research Centre, Bhilai. It is a prospective study which includes 25 patients with 10 Type A, 7 Type B and 8 Type $\mathrm{C}$ fractures of distal femur after fulfilling the inclusion and exclusion criteria.

Results: Mean age of 47.08 years with sex incidence of 3.17:1(M:F). Mode of injury was RTA in 16, simple fall in 6, fall from height in 2 and railway track accident in 1 patient. There were 5-A1, 1-A2, 4-A3, 3-B1, 1-B2, 3-B3, 1$\mathrm{C} 1,4-\mathrm{C} 2$ and $3-\mathrm{C} 3$ fractures. Complication in form of varus angulations was found in 5 cases, shortening occurred in 2 patients, backing out of distal femoral locking screw occurred in 1 patient. Deep infection occurred in 1 patient. Implant failure and varus angulations at fracture site occurred in 1 patient.

Conclusion: We conclude that minimally invasive surgical techniques and with the availability of locking type of plates distal femoral fractures can now be dealt with more precessions and more satisfactory results can be produced.
Keywords: Complication, Muller Classification, Management, Femoral fractures

\section{INTRODUCTION}

Orthopaedic science is also making pace with the velocity of the other world and it has grown up from the Hippocratic age when fracture was treated by external splints and prolonged immobilisation, to the present era of eminent trauma care with rapid fixation and early mobilisation.

Distal femoral fractures often are unstable and comminuted and tend to occur in either elderly or multiply injured patients. Because of the proximity of these fractures to the knee joint, regaining full knee motion and function may be difficult. ${ }^{(1)}$

Distal femoral fractures involving 9$15 \mathrm{~cm}$ from the distal articular surface are much less common than hip fractures and account for about $7 \%$ of all femoral fractures. If fractures of hip are excluded, $31 \%$ of femoral fractures involve the distal portion. ${ }^{(2)}$

In the past 3 decades with the improvement in surgical techniques and implants, popularized by the AO group, there has been a noticeable trend towards surgical management of these fractures. It is now recognized by most orthopaedic surgeons that distal femoral fractures are best treated with open reduction and surgical stabilization. ${ }^{(3)}$

There are various treatment options available for the management of these injuries. Despite the advances in techniques 
and improvement in surgical implants, treatment of distal femoral fractures remains a challenge in many situations. Anatomical reduction of articular surface, stable internal fixation with minimal soft tissue stripping, restoration of limb alignment and early mobilisation have been shown to be effective way of managing most distal femoral fractures. ${ }^{(4)}$ In this study to aim was to study surgical management of distal femoral fractures \& its complication.

\section{MATERIALS \& METHODS}

Twenty five patients having 25 distal femoral fractures with 10 Type A, 7 Type B and 8 Type $C$ fractures of distal femur were treated by open reduction and internal fixation with locking plates, condylar plates and cancellous cannulated screws during the period from August 2008 to March 2010, at Jawaharlal Nehru Hospital and Research Centre Bhilai, C.G. All the 25 patients were available for the study. Fresh \& old cases of distal femoral fractures which are closed type and all supracondylar \& intercondylar extension of distal femoral fractures were included.

Most of the patients were brought to casualty. A careful history was elicited from the patient and/or attenders to reveal the mechanism of injury and the severity of trauma. Clinical assessment of skeletal and soft tissue injuries and general condition was done. The patients who had supracondylar and intercondylar fractures of distal $9 \mathrm{~cm}$ of femur were selected for the study.

Vital signs were recorded. Systemic examination was done. Local examination of the fractured limb in majority of the cases revealed lateral rotation of the limb, swelling at the fracture site, tenderness, abnormal mobility, crepitus and shortening from $1 \mathrm{~cm}$ to $2 \mathrm{~cm}$. Distal neurovascular status was assessed by palpating dorsalis pedis and posterior tibial artery and asking the patient to dorsiflex and evert the foot. Out of 25 patients all were fresh fractures, and they presented to hospital within 0 to 4 days of trauma. X-ray of lower half of thigh including knee joint AP and lateral views were taken. Muller's classification was used. There were 5 type A1, 1 type A2, 4 type A3, 3 type B1,1 type B2, 3 type B3, 1 type $\mathrm{C} 1,4$ type $\mathrm{C} 2$ and 3 type $\mathrm{C} 3$. The injured limb of all the patients were immobilised by skin traction and injectable analgesics were given to relieve pain.

\section{RESULTS}

This series consists of 25 cases of distal femoral fractures with 10 Type A, 7 Type $B$ and 8 Type $C$ fractures of the femur treated surgically by internal fixation with a locking compression plate, simple condylar plates and cancellous cannulated screws between March 2008 to August 2010. All these patients were available for follow up.

There were 19 men and 6 women with an average age of 47.08 years, ranging from 16 years to 78 years. Majority 7 $(28.0 \%)$ of the patients were belonging to the age group between 41 to 50 years followed by the $6(24.0 \%)$ were belonged to the age group between 16 to 30 years, 4 $(16.0 \%)$ were 61 to $70 \&$ more than 70 years and $2(8.0 \%)$ were 31 to 40 years \& 51 to 60 years respectively. The mode of injury was traffic accident in 16 patients, fall in 8 patients, with fall from height in 2 patient and simple fall in 6 patients. In 1 patient mode of injury was Rail track accident. Left femur was involved in $11(44 \%)$ patients and right was involved in $14(56 \%)$ patients.

Table No. 1: Associated injuries of the study subjects.

\begin{tabular}{|c|c|}
\hline Associated Injuries & No. Of Pateitns \\
\hline Ipsilateral patella fracture & 4 \\
\hline Bilateral patella fracture & 1 \\
\hline Ipsilateral tibial condyle fracture & 1 \\
\hline Ipsilaterla tibial shaft fracture & 3 \\
\hline Ipsilateral femur shaft fracture & 1 \\
\hline Ispilateral medial mallolar fracture & 1 \\
\hline Contralateral radius fracture & 1 \\
\hline Total & 9 \\
\hline
\end{tabular}

Table No. 2: Implants used in different type of fractures in the study subjects.

\begin{tabular}{|l|l|l|l|l|}
\hline \multirow{2}{*}{ Implant } & \multicolumn{3}{|l|}{ Type of Fracture } & Total \\
\cline { 2 - 5 } & A & B & C & \\
\hline Locking Compression plus & 5 & 1 & 6 & 12 \\
\hline Spoon Plates & 3 & 0 & 1 & 4 \\
\hline Cancellous Cannualted screw & 1 & 6 & 0 & 7 \\
\hline Condylar plate & 0 & 0 & 1 & 1 \\
\hline Intramedullary femoral nailing & 1 & 0 & 0 & 1 \\
\hline
\end{tabular}


There were 9 of the 25 patients $(36 \%)$ had associated injuries. 4 patients had ipsilateral patella fracture. Out of these 4 one had bilateral patella fracture and one had ipsilateral tibial condyle fracture. 3 patients had ipsilateral tibial shaft fracture of which one had ipsilateral femur shaft fracture. One patient had ipsilateral medial malleolar fracture. One patient had fracture lower end radius of contralateral side (Table No. 1)

Following types of implants were used for the treatment of various types of fractures depending upon severity of fracture, age of the patient, quality of bone and affordability of the patients.

We have used locking compression plates in 12 patients, spoon plates in 4 patients, cancellous cannulated screw in 7 patients, condylar plate in 1 patient and intramedullary femoral nailing in 1 patient.

\section{COMPLICATION}

Intra-operative: No major intra- operative complication was faced while doing these surgeries.

Post Operative Complications: Deep Infection: There was 1 case of Deep infection, which persisted even after appropriate antibiotic treatment after culture and sensitivity. Infection subsided after removal of stitches and thorough lavage of the operative site. This patient also went into delayed union.

\section{Delayed Complications:}

a) Implant Failure: In one patient who was operated with intramedullary nailing, the screws from the distal locking site came out and there was shortening of the limb by 2 $\mathrm{cm}$. It was managed with reduction under general anaesthesia and reapplication of distal locking bolts. The fracture was united in 20 weeks. Still some varus angulation persisted with shortening of $2 \mathrm{cms}$.

b) Non union: No patient in our series had non union.

Table No. 3: Muller Classification for Distal Femoral Fractures.

\begin{tabular}{|l|l|l|l|l|l|}
\hline Muller Classification & Excellent & Good & Moderate & Poor & Total \\
\hline A1 & 3 & 0 & 0 & 2 & 5 \\
\hline A2 & 0 & 0 & 1 & 0 & 1 \\
\hline A3 & 3 & 1 & 0 & 0 & 4 \\
\hline B1 & 2 & 0 & 1 & 0 & 3 \\
\hline B2 & 1 & 0 & 0 & 0 & 1 \\
\hline B3 & 3 & 0 & 0 & 0 & 3 \\
\hline C1 & 1 & 0 & 0 & 0 & 1 \\
\hline C2 & 3 & 0 & 1 & 0 & 4 \\
\hline C3 & 1 & 0 & 0 & 2 & 3 \\
\hline Total & 17 & 1 & 3 & 4 & 25 \\
\hline
\end{tabular}

The fractures were classified according to Muller's classification for distal femoral fractures. There were 5-A1, 1-A2, 4-A3, 3- B1, 1- B2, 4- B3, 1-C1, 4-C2 and $3-\mathrm{C} 3$ fractures. Overall results were excellent in $17(68 \%)$ patients, good in 1 (4\%) patients, moderate in $3(12 \%)$ patients and poor in $4(16 \%)$ patients. Two poor results in A1 group were because of deep infection in one patient and in other one it was because of the ipsilateral mid shaft fracture of femur and tibia.(Table No. 3)

\section{DISCUSSION}

25 cases of distal femoral fractures with 10 Type A, 7 Type B, 8 Type C fractures of the femur were treated by open reduction and internal fixation using different types of imlants. They were followed up for an average of 14.3 months. The purpose of the study was to evaluate the end result of treatment in these patients and to compare with other studies on the same fracture type.

The average age of all cases in this series was 47.08 years. Fracture was more common in age groups between 41-50 years. Our studies average age is similar to study done by Siliski JM ${ }^{(5)}$ and Rademakers MV ${ }^{(6)}$. But average is lesser than the other studies, this probably is because of 
increasing number of youngsters getting this injury because of road traffic accidents.

There were 19 male and 6 female patients, showing male preponderance. Shewring DJ and Meggitt BF ${ }^{(7)}$ reported female preponderance in their series. Giles JB et al ${ }^{(8)}$, Pritchett JW ${ }^{(9)}$ and Siliski JM ${ }^{(5)}$, reported male preponderance.

\section{Complications:}

1. Infection: In this series there was 1case (4\%) of deep infection which was controlled after appropriate antibiotics. The studies by Shewring DJ and Meggitt $\mathrm{BF}^{(7)}$ and by James B Giles et al ${ }^{(8)}$ had no post-operative infection. The study by Siliski JM ${ }^{(5)}$ noticed deep infection in 3 fractures and all of those 3 patients had poor results, which is similar to our study.

2. Shortening: Shortening had occurred in 2 patients ranging from 1 to $2 \mathrm{cms}$.

3. Deformities: Varus deformity of 100 to 150 occurred in 4 patients. Giles JB et al (8) noted more than 50 angulation in 3 patients in his series.

4. Non Union: No case in this series had non-union. Shewring DJ and Meggitt BF (7) noted 2 cases of nonunion in their series.

Out of these 9 patients (36\%) had associated injuries, denoting that the injury was due to high energy trauma. Many other authors have reported associated injuries to the popliteal artery and ligaments of the knee joint. However, in this series there were no vascular and ligamentous injuries.

In our study excellent result was seen in $68 \%$ and good results were seen in 4\%. Excellent to good results in this series is similar to that in the series of Pritchett JW ${ }^{(9)}$ and Kolb K ${ }^{(10)}$. Two poor results in C3 type were due to complex fracture pattern and in two A1 type were due to infection in one patient and ipsilateral shaft of femur and tibia fracture in other one.

\section{CONCLUSION}

Analysis of our results showed that, locking compression plate is a good method of treating closed Type $\mathrm{C}$ and Type A fractures in both young and geriatric age group of patients. Spoon plates can be used in type A fractures with good bone stocks. Cancellous cannulated screw fixation with minimal soft tissue dissection is a good method for treatment of close Type B fractures. Minimally invasive surgeries with good implant purchase helps in early mobilisation of the knee joint and stiffness can be prevented.

We conclude that minimally invasive surgical techniques and with the availability of locking type of plates distal femoral fractures can now be dealt with more precessions and more satisfactory results can be produced.

\section{Acknowledgement: None}

\section{Conflict of Interest: None}

\section{Source of Funding: None}

\section{Ethical Approval: Approved}

\section{REFERENCES}

1. Whittle A. Paige and George W Wood II. "Fractures of Lower Extremity". Chapter 51 in S. Terry Canale (Eds), Campbell's Operative Orthopaedics, 10th edition, Vol. 3, Philadelphia, Mosby, 2003, 2805-2811.

2. Arneson TJ, Melton LJ, Lewallen DG. Epidemiology of diaphyseal and distal femoral fractures in Rochester, Minnesota from 1965 to 1984. Clin Orthop 1988; 234: 188-194.

3. Peter J O'Brien, Robert N. Meek, Piotr A. Blackhut and Henry M. Broekhuyse. "Fractures of the distal femur". Chapter 42 in Robert W. Bucholz and James D. Heckman (Eds), Rockwood and Green's. Fracture in Adults, 5th edition, Lippincott Williams and Wilkins, Philadelphia, 2001, 1731-1773.

4. Perren SM. "Basic aspects of internal fixation". Chapter 1 in M. Allgower (Eds), Manual of Internal fixation, 3rd edition, Springer- Verlag, 1991, 1.1-1.7.

5. Siliski JM, Mahring $M$ and Hofer HP. Supracondylar - intercondylar fractures of 
the femur. Treatment by internal fixation. $\mathrm{J}$ Bone Joint Surg Am 1989; 71 (1): 95-104.

6. Rademakers MV, Kerkhoffs GM, Sierevelt IN, Raaymakers EL, Marti RK. Intraarticular fractures of the distal femur: a long-term follow-up study of surgically treated patients. J Orthop Trauma. 2004 Apr;18(4):213-9.

7. Shewring DJ and Meggitt BF. Fractures of the distal femur treated with the AO dynamic condylar screw. J Bone Joint Surg Br 1992; 74-B: 122-5.

8. Giles JB, DeLee JC, Heckman JD, Keever JE. Supra condylar inter condylar fractures of the femur treated with a supra condylar plate and lag screw. J Bone Joint Surg Am 1982; 64 (A): 864-70.

9. Pritchett JW. Supra condylar fractures of femur. Clin Orthop 1984; 184: 173-7.

10. Kolb K, Grützner P, Koller H, Windisch C, Marx F, Kolb W. The condylar plate for treatment of distal femoral fractures: a longterm follow-up study. Injury. 2009 Apr;40(4):440-8. Epub 2009 Mar 13.

How to cite this article: Shrivastava R, Shrivastava N. To study surgical management of distal femoral fractures \& its complication. International Journal of Research and Review. 2021; 8(6): 40-44. DOI: https://doi.org/10. 52403/ijrr.20210607 